\title{
Coping with Pastoral Burnout Using Christian Contemplative Practices
}

\author{
Thomas V. Frederick ${ }^{1, * \mathbb{D}}$, Yvonne Thai ${ }^{1}$ and Scott Dunbar ${ }^{2}$ \\ 1 Department of Behavioral Sciences, California Baptist University, Riverside, CA 92504, USA; \\ ythai@calbaptist.edu \\ 2 Department of Business, California Baptist University, Riverside, CA 92504, USA; sdunbar@calbaptist.edu \\ * Correspondence: tfrederick@calbaptist.edu
}

Citation: Frederick, Thomas V.,

Yvonne Thai, and Scott Dunbar. 2021.

Coping with Pastoral Burnout Using Christian Contemplative Practices.

Religions 12: 378. https://doi.org/ $10.3390 /$ rel12060378

Academic Editor: Regina

Chow Trammel

Received: 31 March 2021

Accepted: 19 May 2021

Published: 24 May 2021

Publisher's Note: MDPI stays neutral with regard to jurisdictional claims in published maps and institutional affiliations.

Copyright: (C) 2021 by the authors. Licensee MDPI, Basel, Switzerland. This article is an open access article distributed under the terms and conditions of the Creative Commons Attribution (CC BY) license (https:// creativecommons.org/licenses/by/ $4.0 /)$.

\begin{abstract}
Three Christian Devotion Meditation (CDM) practices-lectio divina, centering prayer, and the examen-will be offered to aid in coping with ministerial stress and to prevent burnout. CDM or Christian contemplative practices are uniquely suited to develop the emotional resources pastors need for coping with burnout. The office of the pastor faces pressures which can cause burnout and threaten their ministries and personal relationships. The experience of pastoral burnout consists of acedia. Pastors experience spiritual emptiness due to two unique aspects of pastoral life. First, because pastors often work alongside with their families in the church while simultaneously serving their congregants, they experience inter-role conflict due to the high level of boundary ambiguity between their vocational and family lives. Second, pastors need to rely on their psychological resources to provide for their church members due to the emotional labor required of their positions. Consequently, pastors must rely on emotional labor strategies to respond positively to their congregations, which in turn can lead to emotional exhaustion.
\end{abstract}

Keywords: lectio divina; centering prayer; examen; Christian Devotion Meditation; pastoral burnout; emotional labor; work and family balance

\section{Introduction}

Burnout is becoming an increasing concern for the office of the pastor. Burnout in the pastorate is derived from inter-role conflict suggesting that pastors are uniquely situated to increase risk of burnout as they express their vocation in a community alongside their family. Pastoring means that one lives with one's congregation, which makes inter-role conflict a certainty. Second, pastors tend to experience emotional exhaustion as they support and nurture their congregations. As a result of the emotional investment in the lives of their congregations, pastors need to rely on their psychological resources in order to provide for their church members. When the inevitable conflict arises, pastors must rely on emotional labor strategies, i.e., surface and deep acting, in order to respond positively to their congregations. Emotional labor strategies consume precious psychological resources for pastors which results in their experience of emotional exhaustion. Due to these unique aspects of the pastorate, Christian Devotion Meditation (CDM) or Christian contemplative practices are uniquely suited to develop the emotional resources pastors need for coping with burnout. This article presents three CDM practices for pastors to use-lectio divina, centering prayer, and examen-to stave off and cope with ministerial stress which could lead to burnout.

This article will describe the ravages and causes of burnout. Then, discussion will turn to how the pastorate is a crucible for encouraging burnout via work and family conflict and emotional exhaustion. Finally, the main contribution of this article focuses on how mindfulness practices and their corresponding Christian contemplative practices (or what is more generally known as Christian Devotion Meditation (CDM)) allows one to incorporate Christian accommodative practices with mindfulness, especially for pastors 
experiencing burnout. That is, the unique family and occupation context which pastors and their families inhabit creates a crucible that facilitates higher levels of burnout. The three CDM practices of lectio divina, centering prayer, and the daily exam not only directly address the causes of pastoral burnout, but they also provide Christian spiritual resources that tailor mindfulness practices for pastors seeking to incorporate this type of spirituality into treatment.

\section{Pastoral Burnout}

\subsection{Burnout}

The construct of burnout was coined and first studied in the 1970s by Herbert Freudenberger and Christina Maslach. The current widely accepted definition of burnout is "a prolonged response to chronic emotional and interpersonal stressors on the job, and is defined by the three dimensions of exhaustion, cynicism, and inefficacy" (Maslach et al. 2001, p. 397) Since its inception, burnout scholarship has moved through three distinct stages: 1 . the pioneering phase; 2 . the empirical phase; and 3. the expanding phase. The pioneering phase is the initial phase of the study of burnout as it is now understood and took place in the 1970s and the 1980s. The focus on this initial phase was exploratory in nature and sought to describe and define the phenomenon of burnout. The empirical phase, which took place from the 1980s to the 1990s, saw the phenomenon of burnout move to longitudinal studies, and from qualitative studies to quantitative studies. Additionally, research during this phase branched out to a multitude of occupations (Maslach et al. 2001). The expanding phase followed the empirical phase. Researchers in the expanding phase continued to apply the study of burnout to a wider array of occupations and began to study the effects of technology (email, texts, tablets, computers, smartphones, and applications) on burnout (Dunbar et al. 2020).

Research indicates that burnout can occur in any industry, organization, position, or job type. In short, no burnout-proof career or vocation exists. While the majority of burnout studies are conducted in the medical field (physicians, nurses, intensivists, hospital departments, nonpatient care, ancillary services, residents, volunteers, students, etc.), areas of study continue to expand. Recent studies have researched burnout in populations such as parenting (Roskam et al. 2018), university students (Portoghese et al. 2018), psychiatry (Schonfeld and Bianchi 2021), teachers (Meredith et al. 2020), and athletes (Gerber et al. 2018). Additionally, the relationships between burnout and various psychological phenomena continues to grow. Examples being studied in conjunction with burnout include depression, job performance, cognitive performance, stress, self-esteem, personality traits, job resources, organizational politics, empathy, work overload, supervisor support, and role ambiguity. For example, role ambiguity has a significant effect on job burnout and performance (Wu et al. 2019), and job burnout negatively affects job satisfaction and job performance (Liu et al. 2020). In other words, individuals not understanding their work roles (duties, expected outcomes, procedures/processes, reporting structure, etc.) can experience burnout and low levels of job satisfaction. Weigl et al. (2016) found that emotional exhaustion is related to work overload and low supervisor support. This translates to emotional exhaustion occurring when an individual experiences demands that are perceived to be unreasonable and/or he or she does not receive support from his or her supervisors. Consequences of burnout affect both the organization and the individual experiencing burnout. Burnout can result in employee turnover, neglect, depression, unhappiness, isolation, health problems, attempted suicide, diminished satisfaction and achievement, poor work performance, and substance abuse (Atalayin et al. 2015; Basar and Basim 2016; Taylor and Ayyala 2019; Walburg et al. 2015).

The main instrument for measuring burnout is the Maslach Burnout Inventory (MBI). The MBI was developed in the Empirical Phase and is considered to be the gold standard for measuring burnout (Maslach et al. 2012). To date, five versions of the MBI exist to distinguish between populations: (a) Medical Personnel (MBI-HSS (MP)); (b) Human Service Workers (MBI-HSS); Educators (MBI-ES); (c) General Use (MBI-GS); and (d) Students 
(MBI-S). Each version of the MBI is composed of three scales: (a) Exhaustion or Emotional Exhaustion; (b) Cynicism or Depersonalization; and (c) Professional Efficacy or Personal Accomplishment. One or more versions of the MBI has been translated into 47 languages. When first developed, the authors of the MBI viewed burnout as a process model or phase model, in which one dimension of burnout led to the next dimension of burnout, which led to the last dimension of burnout. For example, the initial stage of emotional exhaustion led to depersonalization, which led to reduced personal accomplishment. However, there has been a move to view burnout as a one-dimensional construct of exhaustion. It is important to note that the preeminent scale for measuring burnout is the emotional, or emotional exhaustion, scale. In fact, the authors of the MBI (Maslach et al. 2018) state, "Exhaustion is often considered the strongest, primary element of burnout, and thus a suitable proxy for the entire phenomenon" (p. 72). Maslach, Jackson, and Leiter also state, "For use in applied settings, a prudent approach when deciding to take action on the basis of burnout scores is to give the most weight to Emotional Exhaustion scores as they are the most reliable" (2018, p. 3). The emotional exhaustion component has also been incorporated in burnout instruments other than the MBI. For example, the Copenhagen Burnout Inventory (CBI) refers to physical and emotional exhaustion.

However, the MBI has received criticism for not adequately reflecting the occupation of the pastor (Francis et al. 2004; Randall 2013). These are two main concerns regarding the relationship of the MBI and pastors: (1) the implied theory to emotional exhaustion drives the other burnout dimensions, and (2) the MBI items themselves do not reflect pastoral ministry, i.e., refer to clients instead of parishioners or congregants. The evidence suggests the modified MBI adequately assesses burnout among pastors (Francis et al. 2004; Randall 2013; Rutledge and Francis 2004); however, emerging research suggests that other theories of pastoral burnout more accurately reflect this unfortunate pastoral concern (see below).

Two concepts that continue to be applied to the phenomenon of burnout are workfamily balance and inter-role conflict. Grzywacz and Carlson (2007, p. 455) define workfamily balance as, "accomplishment of role-related expectations that are negotiated and shared between an individual and his or her role-related partners in the work and family domains". In short, work roles and family roles affect each other and the individual performing in both roles. One role can positively enrich or negatively affect the other role and the individual's stress level. When work and family are in conflict (work-family conflict), individuals can experience stress and burnout (Smith et al. 2019). A study conducted by Greenhaus and Beutell (1985) found that work-family conflict exists due to time constraints formed when one of the roles makes it difficult to successfully perform the requirements of the other role, strain from one of the roles makes it difficult to successfully complete the requirements of the other role, and the specific behaviors of one role make it difficult to successfully complete the requirements of the other role. Research indicates that long work hours and weekend schedules are associated with high levels of work-family conflict (Asiedu et al. 2018). Because pastors routinely work weekends and long hours, work-family conflict can become an issue and can ultimately lead to burnout.

Work-family balance is often studied in conjunction with inter-role conflict. Inter-role conflict is defined as "a form of role conflict in which the sets of opposing pressures arise from participation in different roles" (Greenhaus and Beutell, p. 77). Demands in one role impact the stress in both roles, as well as the other life areas (Smoktunowicz et al. 2017). In short, the pressures, demands, and stress in one role bleed over into the other role, causing conflict. Burnout can be caused by inter-role conflict (Dunbar et al. 2020). Additionally, a study conducted by Kozak et al. (2013) found that burnout can be predicted by inter-role conflict. Pastors may experience high levels of inter-role conflict as they feel an obligation and calling to serve Christ, His church, and their own immediate families. Serving multiple roles can initiate the causes that lead to work-family conflict (time constraints, strain between roles, and specific behavior expectations). 
Ultimately, burnout as the experience of exhaustion as a result of inter-role conflict or work-family balance requires the use of emotional labor as a self-regulation strategy.

\subsection{Emotional Labor}

Service sector workers are required to exert emotional competency while on the job. This concept, known as emotional labor, is the act of expressing socially desired emotions during service transactions. Specifically, it is the management of feelings to create a publicly observable facial and bodily display, which is then sold for a wage and therefore has exchange value (Hochschild 1983, p. 9). It involves managing emotions in order to conform to organizational or professional display rules in order to satisfy job requirements (Shankar and Kumar 2014). Thus, emotional labor involves actively modifying, creating, and altering the expression of emotions in the context of paid employment (Choi and Kim 2015).

\subsection{Surface and Deep Acting}

As individuals attempt to manage their emotions, they can engage in surface acting or deep acting. Surface acting involves simulating emotions that are not actually felt, by changing outward appearances (i.e., facial expression, gestures, or voice tone) when exhibiting the required emotions. Deep acting, on the other hand, is when one attempts to actually experience or feel the emotions that one wishes to display (Ashforth and Humphrey 1993). Unlike surface acting, deep acting involves changing one's inner feelings by altering more than the outward appearance. In surface acting, feelings are changed from the "outside in", whereas in deep acting, feelings are changed from the "inside out" (Hochschild 1983). Utilizing these strategies allows employees to perform the emotional labor that is required of them on the job (Ashforth and Humphrey 1993; Grandey 2003). Research suggests that the demands for emotional labor result in negative outcomes including job satisfaction, memory performance, and depersonalization. It has also been found to be positively related to job stress, hypertension, and heart disease (Mann 2004). Emotional labor has also been found to exacerbate emotional exhaustion and burnout (Zapf 2002).

\subsection{Emotional Labor and Burnout}

Hochschild (1983) argued that there are pernicious effects of both surface acting and deep acting on the laborer. First, portraying emotions that are not felt (SA) creates a sense of strain that she terms emotive dissonance. Ultimately, this dissonance could lead to personal and work-related maladjustment such as poor self-esteem, depression, and cynicism. Second, it is argued that emotional reactions help one to make sense of situations. Deep acting, thus, may distort these reactions and impair one's sense of authentic self thereby impairing one's well-being. Deep acting, then, may lead to self-alienation as one loses touch with his/her authentic self, which could impair one's ability to recognize or experience real emotion (Ashforth 1989). The root problem is the discrepancy between what the service worker is expected to emote and what is actually experienced.

Burnout, viewed from an emotional labor lens, occurs when workers are unable to maintain sufficient psychological distance between the emotional requirements of their job and their sense of self (Shankar and Kumar 2014). Burnout is a result of the stress experienced by the individuals, and anything causing stress and tension is thought to have an effect upon burnout. Burnout research implies that burnout is not an individual stress response, but rather it is related to an individual's relational transactions in the workplace. Specifically, surface acting was found to be related to stress outcomes (Brotheridge and Lee 1998; Brotheridge 1999; Erickson and Wharton 1997; Pugliesi and Shook 1997), whereas deep acting has been found to be related to a greater sense of personal efficacy of work (Brotheridge and Lee 1998). Interaction with people, besides leading to fatigue, requires the regulation of emotions and is thought to trigger burnout (Rafaeli and Sutton 1989). In the studies conducted by Zapf (2002), it was reported that there is a positive correlation between emotional labor and burnout. Brotheridge and Grandey (2002) discovered a 
correlation between emotional exhaustion and the need to prevent the negative feelings. As such, workers employed in the categories of "high emotional labor" jobs (Hochschild 1983) and "high burnout jobs" (Cordes and Dougherty 1993) report significantly higher levels of employee stress than do other workers. Specifically, occupants of health care, social service, teaching, and other "caring" professions are more likely to experience burnout (Cherniss 1993; Jackson et al. 1986; Leiter and Maslach 1988; Schaufeli et al. 1993).

\section{Causes of Burnout and the Pastorate}

Francis has advanced the theory and research on clergy burnout by focusing on the balanced affect model (Francis et al. 2011; Francis et al. 2017; Robbins and Francis 2010). The balanced affect model of burnout understands well-being as a combination of positive and negative affect. That is, negative and positive affect are theorized to be two different psychological phenomena, not ends of the same continuum. Pastoral burnout, from this perspective, is the subjective evaluation of the ratio between ministry satisfaction and emotional exhaustion. Pastors are at greater risk for burnout and other psychological distress when they experience higher levels of emotional burnout and lower levels of ministry satisfaction. Two that end, Francis creates two distinct measures-the Scale of Emotional Exhaustion in Ministry (SEEM) and Satisfaction in Ministry Scale (SIMS) - to operationalize this approach. Francis's research has supported this theory with Presbyterian Clergy (USA) (Francis et al. 2011) and Anglican clergy in England (Francis et al. 2017; Francis et al. 2019).

The Francis Burnout Inventory and the balanced affect model provide much improvement for understanding the unique sources of pastoral burnout and provide tools to assess this experience. The main focus is on the experience of burnout and how one's experience of ministerial satisfaction may provide a buffer to pastoral burnout. That is, pastors that experience high levels of emotional exhaustion and low levels of ministerial satisfaction are most at risk of experiencing burnout. Ministerial satisfaction is associated with ministerial calling. These are two items that load the highest on the SIMS: "The ministry here gives real purpose and meaning to my life" and "I gain a lot of personal satisfaction from fulfilling my functions here" (Francis et al. 2011, p. 16). These items tie directly into calling and purpose in ministry as described below. Ministry satisfaction provides crucial resources for coping with emotional exhaustion.

Work and family conflict is perhaps one of the main challenges of the pastorate. In approaching this inter-role conflict, it is helpful to understand how boundary ambiguity (BA) describes a fluid boundary between the pastor's family and the congregation (Lee 1995; Lee and Iverson-Gilbert 2003). Because there are many overlapping social interactions where both the pastor and his or her family are embedded in the congregation's life, stress and conflict arises as demands are made on the pastor from both the family and the congregation. These demands may be intrusive as when congregants interrupt family life with their needs. Lee (1999) describes these intrusive demands as violating the boundary between the congregation and the pastor's family. For example, boundary ambiguity (BA) on the ministry demands inventory (MDI) consists of items like "congregant came by the pastor's home unannounced" or "family time interrupted by a phone call" (Lee 1999, p. 482). These experiences create conflict with the pastor's family. Additionally, these intrusions may be experienced negatively, especially as they increase in frequency and intensity. Selfregulation strategies may aid the pastor in negotiating BA (Dunbar et al. 2020). Emotional labor provides a heuristic in understanding the psychological challenges pastors face and how these challenges may contribute to burnout. A recent study adopted a dyadic level of analysis to understand the interpersonal effects of ministry demands (Kim et al. 2016). Both pastors and their spouses responded to the Ministry Demands Inventory (Lee 1999). The primary factor for ministry couples' well-being is associated with their perceptions of ministry demands and not the severity of those demands.

Pastors experience the working conditions associated with emotional labor (Hochschild 1983) as they have repeated interpersonal contact with the public and are expected 
to manage their own emotions in addition to the emotions of those under their care (Kinman et al. 2011). Evidence demonstrates that parishioners more frequently approach pastors for help and support during times of psychological distress or trauma compared to other counselors or mental health professionals (Chalfant et al. 1990; Stanford and McAlister 2008). However, many members of the clergy report lacking the skills and support needed to effectively manage the emotional demands of their work ( $\mathrm{O}^{\prime} \mathrm{Kane}$ and Millar 2001). In their study, Kinman et al. (2011) found significant associations between emotional labor, greater psychological distress, and lowered job satisfaction in a sample of UK-based clergy. Specifically, results of their study demonstrated that members of the clergy who perform emotional labor more frequently and intensely, and who perceive dissonance between emotions that are genuinely felt compared to those that are required for the job role, tend to report greater psychological distress and reduced intrinsic job satisfaction.

\section{Burnout as Lack of Calling and Acedia}

Pastoral burnout is better described along the lines of questioning one's experience of calling and acedia (Frederick et al. 2018b) similar to the balanced affect model. Due to the high levels of stress resulting from BA as well as the emotional labor required to minister to one's congregation, pastors may necessarily begin to question God's call on their life. That is, their identity as a pastor may be questioned. Wilson (2021, p. 23) reminds us that "the role of pastor is inextricably connected to a particular people for whom and to whom the pastor is covenantally responsible". This covenantal responsibility is reflected in the call of God through the congregation to the pastor. Intense conflict between the pastor's family and congregation (or the pastor and the congregation) creates stress and potentially burnout. As a result of this conflict, as described in BA above, pastors may begin to question their call—their identity as a pastor (Dunbar et al. 2020; Frederick and Dunbar 2019). This is one dimension of burnout unique to pastors.

Next, acedia describes the emotional emptiness, uncaring attitude, and lethargy associated with the psychological experience of burnout (Frederick et al. 2018b). Care is the virtue used to describe productive, meaningful, and prosocial work associated with being an adult (Capps [1987] 2000). Acedia, on the other hand, reflects an absence of care. Acedia entails a fundamental apathy that is reflected in unconcern and lack of energy. For pastors, apathy is expressed "in a loss or emptying of the motivational and compassionate aspects of the individual engaged in helping others" (Frederick et al. 2018a, p. 270). Compassionate shepherding of one's congregation is crucial to the pastor, and apathy reflects the psychological depletion of the necessary resources to provide that shepherding. Apathy connotes a self-depletion of psychological resources. These resources aid the pastor in caring for the congregation and for his or her family (See Capps 1993).

Finally, acedia as indifference describes how care is proffered (Frederick et al. 2018b). "Indifference entails lack of care regarding distressing situations and individual suffering" (Frederick et al. 2018a, p. 270). Under the effects of indifference, the pastor addresses the needs of congregants and family members out of a sense of obligation without demonstrating emotional connection and concern for the actual needs of those being cared for. Indifference describes how pastors go through the motions of providing care while maintaining emotional distance from those in need. This indifference objectifies both the congregation and the pastor's family by removing the emotional and psychological connection in humanizing the care being offered.

Apathy and indifference not only reflect depleted psychological resources, but they also reflect spiritual dryness. At its most devastating and depleting level, acedia means lack of care and connection for God (Capps [1987] 2000). That is, the spiritual lethargy whereby pastors become apathetic and indifferent to the needs of others also results in alienation and isolation from God, the maker of those in need. God's divine revelation is an act of ministry. Therefore, ministry and ministers always reveal something (positive or negative) regarding God's character (Anderson 1997) as ministry is given on God's behalf. When the 
pastor is apathetic and indifferent to others, it reflects apathy and indifference toward God. This makes burnout a spiritual phenomenon at least as much as a psychological one.

Burnout as resulting from BA is best described as questioning one's calling as a pastor as well as experiencing acedia. Both calling and acedia describe the psychological and spiritual effects on the self of the pastor which further impact the congregation and the pastor's family. Additionally, calling and acedia reflect the two dimensions associated with the balanced affect model (Francis et al. 2011; Francis et al. 2017; Francis et al. 2019; Robbins and Francis 2010). Ministry satisfaction is derived from the Lord who calls and ordains ministry as well as provides the ultimate purpose of that ministry. Acedia as emotional exhaustion reflects the negative emotional experiences of apathy and indifference (The treatment of acedia as a spiritual condition is the use of Christian spiritual disciplines in order to enliven the pastor's spirit).

\section{Treatments for Burnout Tailored for the Pastorate}

Research suggests that individuals practicing mindfulness have lower levels of burnout and that mindfulness can be a protective factor against individuals becoming burned-out. In short, the ability of an individual to be consciously aware of the current moment may reduce burnout and provide a buffer against burnout (Braun et al. 2017; Sox et al. 2018). Further, lower levels of mindfulness have been associated with higher levels of burnout (Frederick et al. 2018b). One concern is the appropriateness of mindfulness approaches for Christians due to the Buddhist influence and worldview behind these practices. Buddhist psychology is foundational for mindfulness practices and interventions developed for psychotherapy (Grabovac et al. 2011). Additionally, increasing spirituality has been demonstrated as an outcome of MBSR programs, despite model developers specifically trying to distance from Buddhist spirituality while incorporating mindfulness into interventions (Labelle et al. 2015). In other words, clients have increased spirituality despite the intentional efforts of model developers to remove the explicit Buddhist background and context of mindfulness practices.

The three Christian contemplative practices of the lectio divina, centering prayer, and the examen, provide the spiritual disciplines needed to address burnout in the pastorate. We are approaching these contemplative practices from an Ignatian spiritual perspective ( Frederick and Muldoon 2020). The rationale for using Ignatian spiritual practices involves its focus on deepening intimacy with God, its focus on work, especially on call, and emphasis on love. Ignatian spiritual practices encourage deeper intimacy with God via engaging with life and the world, making this a communal or relationship focused approach. Next, Ignatian spiritual practices foster a sense of calling which is connected to one's identity as an envoy of the God. Engagement with the world expresses one's calling. Finally, this type of spiritual practice encourages the deepening love of God based on intimacy and calling.

\subsection{Lectio Divina}

Lectio divina is an intentional contemplative practice designed to allow the practitioner to imaginatively engage in scripture reading. Further, lectio divina allows one to actively discern God's active involvement in one's experience, especially as the participant engages the imagination while reading the scripture. A specific approach to imaginative Bible reading will enhance how pastors understand and live out their calling. In other words, the lectio divina offered below is intended to address pastors' concerns with calling which arises from burnout.

Lectio divina is a scriptural drama meditation (CDM) type of spiritual intervention as defined by Garzon (2013). This type of CDM encourages the individual to engage the imagination to visualize being part of a specific scriptural scene. Knabb and Frederick (2017); see also (Knabb et al. 2017) incorporated lectio divina into a multiweek intervention for Christians that worry. This intervention demonstrated promising results.

Lectio divina is a spiritual practice of developing a life lived in response to God's revelation in Jesus Christ. This is reflected in the spirituality encouraged in the gospel of 
Mark (Barton 1992). Mark's gospel opens with the declaration of the word of prophecy from Isaiah announcing that Jesus Christ is the one described in the prophecy. Throughout Jesus' ministry, from demonic encounters to healing to teaching, he embodies and fulfills the word of God. Jesus typifies life under God's word, and he teaches others through his words and deeds to do likewise. Barton eloquently writes of spirituality in the Gospel of Mark focusing on "life under God," meaning that it is "a response to the revelation of the divine" (1992, p. 43). Lectio divina allows pastors an imaginative experience of life under the divine revelation of God and the Bible.

A lectio divina practice takes around twenty minutes. Pastors should begin by sitting comfortably in a chair, positioned in an upright yet relaxed position. Pastors should say a brief prayer welcoming God's active, loving presence during the reading. Time should be given so that the pastor enters a relaxed state where the breath is slowed (perhaps five to ten minutes on deep breathing). The passage the pastors should read focus on Jesus' baptism. The passage to read is Matthew 3: 13-17:

Then Jesus came from Galilee to John at the Jordan, to be baptized by him. But John tried to stop Him, saying, "I need to be baptized by You, and yet You come to me?"

Jesus answered him, "Allow it for now, because this is the way for us to fulfill all righteousness". Then he allowed Him to be baptized.

After Jesus was baptized, He went up immediately from the water. The heavens suddenly opened for Him, and He saw the Spirit of God descending like a dove and coming down on Him. And there came a voice from heaven:

This is My beloved Son.

I take delight in Him!

As the pastor slowly reads this passage, he or she should engage the imagination and enter the story. Some questions to aid the imagination: (1) What do you see and hear as you witness the interaction between John the Baptist and Jesus? (2) How does the sun and sand feel on your body? (3) Are there many people present? (4) What surprises you about John the Baptist saying he needs to be baptized by Jesus? (5) Did you hear the words and see the spirit descending on Jesus? What was that like? How did it make you feel? (6) Imagine Jesus speaking these words over you during your baptism. How does hearing Jesus say these words over you make you feel? After sitting with the imagination in this story and contemplating these questions, the pastor should say a prayer of thanksgiving over the entire experience.

The baptismal story and ritual provide important insights into the nature of the pastor's call first as a disciple, then as a shepherd of God's flock. The insights developed from the lectio divina allow the pastor to remember God's embrace as well as empowerment to fulfill the call to the pastorate. This spiritual exercise speaks directly to the brokenness of the pastor's experience of burnout that challenges God's calling.

\subsection{Centering Prayer}

Centering prayer is a four-step process that encourages pastors to surrender to God's active, loving presence in all experience, both positive and negative. Gregg Blanton (2011, 2019) has contributed significantly to Evangelicals wanting to incorporate centering prayer into their spiritual practices by describing the benefits and process for using this spiritual discipline. Practitioners utilize Keating (2014) four guidelines to foster an interior silence that is crucial to move through the four moments of centering prayer. This inner silence facilitates surrendering to God's active, loving presence in the inner life of the Christian. First, pastors should identify a sacred word. This word represents the pastor's desire and intent to engage with God, especially within inner experience. Next, one experiences rest and inner peace as the sacred word allows movement regarding one's usual awareness. That is, pastors begin to repeat the sacred word as they attend to their inner experiences. As their minds wander and more experiences arise, the sacred word becomes a focal point 
for God's active, loving presence. As practitioners gain more and more experience with the sacred word and experience more rest, more negative experiences should surface. The term for this is "unloading" (Keating 2014), which is the third moment. Finally, evacuation happens due to releasing and accepting one's experiences, positive and negative, in God's loving presence. Practitioners usually spend twenty minutes in focused attention on one's thoughts and the sacred word (Blanton 2011,2019). Blanton's work on centering prayer is a useful resource for Christians. There is also a workbook that provides guidance on using centering prayer with chronic worry (Knabb and Frederick 2017).

Centering prayer is one spiritual practice that fosters a sense of the divine presence. Experiencing the presence of the divine is a central theme of the spirituality of Matthew (Barton 1992). In Matthew, the emphasis is on "God is with us" or Immanuel. Immanuel is emphasized in the genealogy of Jesus presented in Matthew one. The title of Matthew literally means book of genesis-biblos geneseos in Greek (Barton 1992). The spirituality Jesus teaches in Matthew views God as fatherly which ties into God's providential care for his people; it also emphasizes God the Father's ultimate and final authority over the cosmos, and it fosters the spiritual relationship with God the father as mediated through Jesus Christ. Centering prayer fosters these same experiences as pastors use it to develop increasing awareness of God's active and loving presence in all of experience.

Christ-centered present moment awareness is another type of Christian devotion mediation as described by Garzon (2013). Centering prayer and the examen are examples of this type of spiritual intervention. Knabb and Vazquez (2018) developed a Christcentered intervention for daily stress using the Jesus Prayer (See also Vazquez and Jensen 2020). This approach incorporated a 20-minute daily practice of saying the Jesus Prayer ("Lord, Jesus Christ, Son of God, Have Mercy on me, a sinner,"; Talbot 2013). Results suggested that this approach provides relief for daily stress.

Centering prayer provides the spiritual invigoration needed to redress acedia expressed as apathy. "In Centering Prayer, you put yourself at God's disposal. The person is only interested in being open to God so the results are up to God" (Blanton 2011, p. 136). Centering prayer facilitates pastors surrendering to God's loving, active presence in their lives as God leads, guides, directs, and walks along with pastors through their struggles with burnout. Further, centering prayer infuses daily life with God's living, active, loving presence. Ferguson et al. (2010) describe how centering prayer increased Christians' collaborative relationship with God, (b) decreased a deferring religious coping style, and (c) decreased religious coping self-directed style while reducing stress and worry. This suggests that centering prayer fosters the building of relationships with God, and these relationships have positive psychological benefits (See Frederick and White 2015; Johnson et al. 2009). Centering prayer is not solely about ameliorating negative experiences, it is about connection with God at deep levels. Spiritual intimacy revitalizes the soul ravaged by acedia (Capps [1987] 2000), and centering prayer is a spiritual discipline useful to accomplish this goal.

\subsection{The Daily Examen}

The examen focuses on the individual's intentions, motivations, and attitudes in the present and how these subjective experiences align with God's intentions (Frederick and Muldoon 2020). In other words, the examen as a spiritual discipline allows Christians to see God's activity in daily life. Further, reflecting on how one responds to God's activity illuminates one's inner motivations. "Reflecting on one's actions and motives in God's loving presence allows one to deepen intimacy and freedom to live out one's purpose" (Frederick and Muldoon 2020, p. 16). This focus on motivation, action, and purpose is crucial to connecting the calling of being a pastor with shepherding the congregation, which speaks to acedia as indifference.

The examen reflects Jesus' spiritual practices for seeing God's active presence in the moment. A telling example of this is Jesus' teaching on anxiety (Matthew 6: 25-27): 
Don't worry about your life, what you will eat or what you will drink; or about your body, what you will wear. Isn't life more than food and the body more than clothing? Consider the birds of the sky: They don't sow or reap or gather into barns, yet your heavenly Father feeds them. Aren't you worth more than they?

This passage follows the famous Lord's Prayer and the Sermon on the Mount (Matthew 5). The focus here is following Jesus' teaching and orienting one's heart to seeing God's providential care, and humbly submitting to God's will orients one to God's intended purpose for the cosmos. Further, once this orientation occurs, anxiety is ameliorated because Christians understand Father God's providential presence and care-God is with us-in the midst of daily life and experience.

A useful process for practicing the examen comes from Ignatian Spirituality (https: //www.ignatianspirituality.com/ignatian-prayer/the-examen/, accessed on 15 March 2021):

1. Become aware of God's presence.

2. Review the day with gratitude.

3. Pay attention to your emotions.

4. Choose one feature of the day and pray from it.

5. Look toward tomorrow.

This process is best utilized with daily journaling so patterns may be identified. These patterns reflect one's inner motivation and how that motivation is reflected in one's emotional experience as well as action.

The metaphor of a compass may aid here (Frederick and Muldoon 2020). The emotions, in Ignatian spirituality, allow pastors to see where their hearts or inner experiences are oriented-towards or away from God. Moments of consolation express times when pastors live out their calling and express God's beliefs, attitudes, and actions to others. Moments of desolation describe those times pastors express attitudes, beliefs, or actions away from God's desires. Notice that consolation and desolation are not positive and negative feelings, respectively. Sometimes a pastor may have a negative feeling that is actually expressing God's attitude, belief, and action (moment of consolation) during a challenging ministry experience.

The examen is a useful spiritual discipline to address acedia as indifference. With the examen's focus on purposeful action and call, it directly addresses both the motivational and action aspects of indifference. The examen fosters a deep reflection on the pastor's inner life, and how this life reflects God's call. The examen also orients one's inner motivations to be authentically expressed in one's action.

\section{Conclusions}

This paper described how pastors experience burnout due to work and family conflict. Work and family conflict is most aptly described as boundary ambiguity, which takes an emotional toll on the pastor. Boundary ambiguity and conflict leads the pastor to question the call to be a pastor. This emotional experience is described as acedia which contains two dimensions-apathy and indifference. Apathy describes the emotional depletion and emptiness pastors experience as a result of burnout. Indifference describes the depersonalized provision of care to others as a result of burnout. Lectio divina, centering prayer, and the examen are offered as ways in which pastors may experience spiritual reinvigoration after burnout.

Author Contributions: T.V.F.-Introduction, Literature Review, Pastors and Burnout, Burnout as Lack of Calling and Acedia, Entire section of Christian Contemplative Practices Designed for Pastors, and Conclusions. Y.T.-Emotional Labor, Surface and Deep Acting, Emotional Labor and Burnout. S.D.-Burnout, work-family balance, and inter-role conflict. All authors have read and agreed to the published version of the manuscript.

Funding: This research received no external funding. 
Institutional Review Board Statement: Not applicable.

Informed Consent Statement: Not applicable.

Data Availability Statement: Not applicable.

Conflicts of Interest: The authors declare no conflict of interest.

\section{References}

Anderson, Ray S. 1997. The Soul of Ministry. Louisville: John Knox Press.

Ashforth, Blake E. 1989. Of canned laughter and political handlers: The erosion of spontaneity and authenticity in social life. Paper presented at the Annual Meeting of the Canadian Psychological Association, Halifax, NS, Canada, June.

Ashforth, Blake E., and Ronald H. Humphrey. 1993. Emotional Labor in Service Roles: The Influence of Identity. Academy of Management Review 18: 88-115. [CrossRef]

Asiedu, Elsie Eunice Amoo, Francis Annor, Kwesi Amponsah-Tawiah, and Kwasi Dartey-Baah. 2018. Juggling Family and Professional Caring: Role Demands, work-family Conflict and Burnout among Registered Nurses in Ghana. Nursing Open 5: 611-20. [CrossRef]

Atalayin, Cigdem, Murat Balkis, Huseyin Tezel, Banu Onal, and Gul Kayrak. 2015. The prevalence and consequences of burnout on a group of preclinical dental students. European Journal of Dentistry 9: 356-63. [CrossRef]

Barton, Scott C. 1992. The Spirituality of the Gospel. London: SPCK.

Basar, Ufuk, and Nejat Basim. 2016. A cross-sectional survey on consequences of nurses' burnout: Moderating role of organizational politics. Journal of Advanced Nursing 72: 1838-50. [CrossRef]

Blanton, P. Gregg. 2011. The other mindful practice: Centering prayer and psychotherapy. Pastoral Psychology 60: 133-47. [CrossRef]

Blanton, P. Gregg. 2019. Contemplation and Counseling: An Integrative Model for Practitioners. Grand Rapids: IVP Academic.

Braun, Sarah E., Stephen M. Auerbach, Bruce Rybarczyk, Bennett C. Lee, and Stephanie Call. 2017. Mindfulness, burnout, and effects on performance evaluations in internal medicine residents. Advances in Medical Education and Practice 8: 591-97. [CrossRef]

Brotheridge, Celeste. 1999. Unwrapping the black box: A test of why emotional labour may lead to emotional exhaustion. In Proceedings of the Administrative Sciences Association of Canada (Organizational Behaviour Division). Edited by Daniel Miller. Saint John: Administrative Sciences Association of Canada, pp. 11-20.

Brotheridge, Celeste M., and Alicia Grandey. 2002. Emotional labour and burnout: Comparing two perspectives of "people work". Journal of Vocational Behavior 60: 17-39. [CrossRef]

Brotheridge, Celeste M., and Raymond T. Lee. 1998. On the dimensionality of emotional labour: Development and validation of the Emotional Labour Scale. Paper presented at the First Conference on Emotions in Organizational Life, San Diego, CA, USA, August 6-8.

Capps, Donald. 2000. Deadly Sins and Saving Virtues. Eugene: Wipf and Stock Publishers. First published 1987.

Capps, Donald. 1993. The Depleted Self: Sin in a Narcissistic Age. Philadelphia: Fortress.

Chalfant, Paul H., Petter L. Heller, Alden Roberts, David Briones, Salvador Aguirre-Hochbaum, and Walter Farr. 1990. The clergy as a resource for those encountering psychological distress. Review of Religious Research 31: 305-13. [CrossRef]

Cherniss, Cary. 1993. Role of Professional Self-Efficacy in the Etiology and Amelioration of Burnout. In Professional Burnout: Recent Developments in Theory and Research. Edited by Wilmar B. Schaufeli, Christina Maslach and Tadeusz Marek. Series in Applied Psychology: Social Issues and Questions; Philadelphia: Taylor and Francis, pp. 135-49. ISSN 1048-8146.

Choi, Yeong-Gyeong, and Kyoung-Seok Kim. 2015. A Literature Review of Emotional Labor and Emotional Labor Strategies. Universal Journal of Management 3: 283-90. [CrossRef]

Cordes, Cynthia L., and Thomas W. Dougherty. 1993. A review and an integration of research on job burnout. Academy of Management Review 18: 621-56. [CrossRef]

Dunbar, Scott, Thomas Frederick, Yvonne Thai, and John Gill. 2020. Calling, Caring, and Connecting: Burnout in Christian Ministry. Mental Health, Religion and Culture 23: 173-86. [CrossRef]

Erickson, Rebecca J., and Amy S. Wharton. 1997. Inauthenticity and Depression: Assessing the Consequences of Interactive Service Work. Work and Occupation 24: 188-213. [CrossRef]

Ferguson, Jane K., Eleanor W. Willemsen, and MayLynn V. Castañeto. 2010. Centering Prayer as a Healing Response to Everyday Stress: A Psychological and Spiritual Process. Pastoral Psychology 59: 305-29. [CrossRef]

Francis, Leslie J., Stephen H. Louden, and Christopher J. F. Rutledge. 2004. Burnout among Roman Catholic Parochial Clergy in England and Wales: Myth or Reality? Review of Religious Research 46: 5-19. [CrossRef]

Francis, Leslie J., Andrew Village, Mandy Robbins, and Keith Wulff. 2011. Work-Related Psychological Health among Clergy Serving in the Presbyterian Church (USA): Testing the Idea of Balanced Affect. Review of Religious Research 53: 9-22. [CrossRef]

Francis, Leslie, Patrick Laycock, and Christine Brewster. 2017. Work-Related Psychological Wellbeing: Testing the Balanced Affect Model among Anglican Clergy. Religions 8: 118. [CrossRef]

Francis, Leslie J., Patrick Laycock, and Henry Ratter. 2019. Testing the Francis Burnout Inventory among Anglican Clergy in England. Mental Health, Religion and Culture 22: 1057-67. [CrossRef]

Frederick, Thomas V., and Scott E. Dunbar. 2019. A Christian Approach to Work and Family Burnout: Calling, Caring, and Connecting. Maryland: Lexington Books. 
Frederick, Thomas V., and Timothy P. Muldoon. 2020. Ignatian Spirituality and Psychotherapy. Journal of Psychology and Christianity 39: 12-23.

Frederick, Thomas, and Kristen M. White. 2015. Mindfulness, Christian Devotion Meditation, Surrender, and Worry. Mental Health, Religion and Culture 18: 850-58. [CrossRef]

Frederick, Thomas V., Scott Dunbar, and Yvonne Thai. 2018a. Burnout in Christian Perspective. Pastoral Psychology 67: 267-76. [CrossRef]

Frederick, Thomas V., Scott Dunbar, Susan Purrington, Sarah Y. Fisher, and Richard Ardito. 2018b. Exploring the relative contributions of differentiation of self and mindfulness for predicting burnout. In Meditation: Practice, Techniques, and Health Benefits. Edited by Lucia Brewer. New York: Nova Science Press, pp. 185-204.

Garzon, Fernando. 2013. Christian devotional meditation for anxiety. In Evidence-Based Practices for Christian Counseling and Psychotherapy. Edited by Evertte Worthington, Eric Johnson, Joshua Hook and Jamie Aten. Downers Grove: InterVarsity Press, pp. 59-80.

Gerber, Markus H. Gustafsson, Harald Seelig, Michael Kellmann, Sebastian Ludyga, Flora Colledge, and Renzo Bianchi. 2018. Psychology of sport and exercise. Psychology of Sport and Exercise 39: 104-13. [CrossRef]

Grabovac, Andrea D., Mark A. Lau, and Brandilyn R. Willett. 2011. Mechanisms of mindfulness: A Buddhist psychological model. Mindfulness 2: 154-66. [CrossRef]

Grandey, Alicia A. 2003. When 'the show must go on': Surface and deep acting as determinants of emotional exhaustion and peer-rated service delivery. Academy of Management Journal 46: 86-96.

Greenhaus, Jeffrey H., and Nicholas J. Beutell. 1985. Sources of Conflict between Work and Family Roles. The Academy of Management Review 10: 76-88. [CrossRef]

Grzywacz, Joseph G., and Dawn S. Carlson. 2007. Conceptualizing Work-Family Balance: Implications for Practice and Research. Advances in Developing Human Resources 9: 455-71. [CrossRef]

Hochschild, Arlie R. 1983. The Managed Heart. Berkeley: University of California Press.

Jackson, Susan E., Richard L. Schwab, and Randall S. Schuler. 1986. Toward an Understanding of the Burnout Phenomenon. Journal of Applied Psychology 71: 630-40. [CrossRef]

Johnson, Mary E., Ann M. Dose, Teri Britt Pipe, Wesley O. Petersen, Mashele Huschka, Mary M. Gallenberg, Prema Peethambaram, Jeff Sloan, and Marlene H. Frost. 2009. Centering Prayer for Women Receiving Chemotherapy for Recurrent Ovarian Cancer: A Pilot Study. Oncology Nursing Forum 36: 421-28. [CrossRef]

Keating, Thomas. 2014. Intimacy with God: An Introduction to Centering Prayer. New York: Crossroad.

Kim, Seong-Hyeon, Takisha M. Corbett, Nathaniel Strenger, and Cameron Lee. 2016. An Actor-Partner Interdependence Analysis of the ABC-X Stress Model among Clergy Couples. Psychology of Religion and Spirituality 8: 65-76. [CrossRef]

Kinman, Gail, Obrene McFall, and Joanna Rodriguez. 2011. The Cost of Caring? Emotional Labour, Wellbeing and the Clergy. Pastoral Psychology 60: 671-80. [CrossRef]

Knabb, Joshua J., and Thomas V. Frederick. 2017. Contemplative Prayer for Christians with Chronic Worry. New York: Routledge.

Knabb, Joshua J., and Veola E. Vazquez. 2018. A randomized controlled trial of a 2-week internet-based contemplative prayer program for Christians with daily stress. Spirituality in Clinical Practice 5: 37-53. [CrossRef]

Knabb, Joshua J., Thomas V. Frederick, and George Cumming II. 2017. Surrendering to God's providence: A three-part study on Providence-Focused Therapy for Recurrent Worry (PFT-RW). Psychology of Religion and Spirituality 9: 180-96. [CrossRef]

Kozak, Agnessa, Maren Kersten, Zita Schillmöller, and Albert Nienhaus. 2013. Psychosocial Work-Related Predictors and Consequences of Personal Burnout among Staff Working with People with Intellectual Disabilities. Research in Developmental Disabilities 34: 102-15. [CrossRef] [PubMed]

Labelle, Laura E., Linette Lawlor-Savage, Tavis S. Campbell, Peter Faris, and Linda E. Carlson. 2015. Does self-report mindfulness mediate the effect of Mindfulness-Based Stress Reduction (MBSR) on spirituality and posttraumatic growth in cancer patients? The Journal of Positive Psychology 10: 153-66. [CrossRef]

Lee, Cameron. 1995. Rethinking Boundary Ambiguity from an Ecological Perspective: Stress in Protestant Clergy Families. Family Process 34. [CrossRef] [PubMed]

Lee, Cameron. 1999. Specifying Intrusive Demands and Their Outcomes in Congregational Ministry: A Report on the Ministry Demands Inventory. Journal for the Scientific Study of Religion 38. [CrossRef]

Lee, Cameron, and Judith Iverson-Gilbert. 2003. Demand, Support, and Perception in Family-Related Stress among Protestant Clergy. Family Relations 52. [CrossRef]

Leiter, Michael P., and Christine Maslach. 1988. The impact of interpersonal environment on burnout and organizational commitment. Journal of Organizational Behavior 9: 297-308. [CrossRef]

Liu, Cong, Jiming Cao, Peng Zhang, and Guangdong Wu. 2020. Investigating the relationship between work-to-family conflict, job burnout, job outcomes, and affective commitment in the construction industry. International Journal of Environmental Research and Public Health 17: 5995. [CrossRef]

Mann, Sandi. 2004. 'People- Work': Emotional management, stress and coping. British Journal of Guidance and Counselling 32: 205-22. [CrossRef]

Maslach, Christina, Wilmar Schaufeli, and Michael Leiter. 2001. Job Burnout. Annual Review of Psychology 52: 397-422. [CrossRef] [PubMed] 
Maslach, Christina, Wilmar Schaufeli, and Susan Jackson. 2012. Making a significant difference with burnout interventions: Researcher and practitioner collaboration. Journal of Organizational Behavior 33: 296-300. [CrossRef]

Maslach, Christina, Susan Jackson, and Michael Leiter. 2018. Maslach Burnout Inventory Manual. Available online: https://www. mindgarden.com/maslach-burnout-inventory-mbi/686-mbi-manual-print.html\#horizontalTab1 (accessed on 20 May 2021).

Meredith, Chloé, William Schaufeli, Charlotte Struyve, Machteld Vandecandelaere, Sarah Gielen, and Eva Kyndt. 2020. Burnout contagion' among teachers: A social network approach. Journal of Occupational and Organizational Psychology 93: 328-52. [CrossRef]

O'Kane, Seamus, and Rob Millar. 2001. An investigation into the counselling-type work of Roman Catholic priests: A survey of one diocese in Northern Ireland. British Journal of Guidance and Counselling 29: 323-35. [CrossRef]

Portoghese, Igor, Michael Leiter, Christina Maslach, Michael Galletta, Fabio Porru, Ernesto DAloja ', and Marcello Campagna. 2018. Measuring burnout among university students: Factorial validity, invariance, and latent profiles of the Italian version of the Maslach Burnout Inventory Student Survey (MBI-SS). Frontiers in Psychology 9: 2105. [CrossRef]

Pugliesi, Karen, and Scott L. Shook. 1997. Gender, jobs, and emotional labor in a complex organization. In Social Perspectives on Emotion. Edited by Rebecca J. Erickson and Beverley Cuthbertson-Johnson. Stamford, CT: JAI Press Inc., vol. 4, pp. $283-316$.

Rafaeli, Anat, and Robert I. Sutton. 1989. The Expression of Emotion in Organizational Life. Research in Organizational Behavior 11: 1-42.

Randall, Kelvin J. 2013. Clergy Burnout: Two Different Measures. Pastoral Psychology 62: 333-41. [CrossRef]

Robbins, Mandy, and Leslie Francis. 2010. Work-Related Psychological Health and Psychological Type among Church of England Clergywomen. Review of Religious Research 52: 57-71.

Roskam, Isabelle, Maria-Elena Brianda, and Moïra Mikolajczak. 2018. A step forward in the conceptualization and measurement of parental burnout: The parental burnout assessment (PBA). Frontiers in Psychology 9: 758. [CrossRef]

Rutledge, Christopher J. F., and Leslie J. Francis. 2004. Burnout Among Male Anglican Parochial Clergy in England: Testing a Modified form of the Maslach Burnout Inventory. Research in the Social Scientific Study of Religion 15: 71-93.

Schaufeli, William B., Christine Maslach, and Tadeusz Marek. 1993. The future of burnout. In Professional Burnout: Recent Developments in Theory and Research. Edited by Wilmar B. Schaufeli, Christina Maslach and Tadeusz Marek. Washington: Taylor and Francis, pp. 253-59.

Schonfeld, Irvin Sam, and Renzo Bianchi. 2021. Psychiatrist burnout. The American Journal of Psychiatry 178: 204. [CrossRef] [PubMed]

Shankar, Binayak, and Sandeep Kumar. 2014. Emotional Labour and Burnout Relationship: Role of Social Support and Coping. Indian Journal of Community Psychology 10: 263-77.

Smith, Todd D., David M. DeJoy, Mari-Amanda (Aimee) Dyal, and Gaojian Huang. 2019. Impact of Work Pressure, Work Stress and Work-Family Conflict on Firefighter Burnout. Archives of Environmental and Occupational Health 74: 215-22. [CrossRef] [PubMed]

Smoktunowicz, Ewelina, Roman Cieslak, and Evangelia Demerouti. 2017. Interrole Conflict and Self-Efficacy to Manage Work and Family Demands Mediate the Relationships of Job and Family Demands with Stress in the Job and Family Domains. Anxiety, Stress, and Coping 30: 485-97. [CrossRef]

Sox, Colin, Christine Cheston, Catherine Michelson, and Yarden Fraiman. 2018. Persistent burnout and mindfulness in pediatric internship. Academic Pediatrics 18: e37. [CrossRef]

Stanford, Matthew, and Kandace McAlister. 2008. Perceptions of serious mental illness in the local church. Journal of Religion, Disability and Health 12: 144-253. [CrossRef]

Talbot, John. 2013. The Jesus Prayer: A Cry for Mercy, a Path of Renewal. Downers Grove: InterVarsity Press.

Taylor, George A., and Rama S. Ayyala. 2019. The hidden consequences of burnout in pediatric radiology. Pediatric Radiology 49: 712-13. [CrossRef] [PubMed]

Vazquez, Veola E., and Gregory R. Jensen. 2020. Practicing the Jesus Prayer: Implications for Psychological and Spiritual Well-Being. Journal of Psychology and Christianity 1: 65-74.

Walburg, Vera, Dany Moncla, and Aurélie Mialhes. 2015. Burnout among high-school students and cannabis use, consumption frequencies, abuse and dependence. Child and Youth Care Forum 44: 33-42. [CrossRef]

Weigl, Matthias, Nicole Stab, Isabel Herms, Peter Angerer, Winfried Hacker, and Jürgen Glaser. 2016. The associations of supervisor support and work overload with burnout and depression: A cross-sectional study in two nursing settings. Journal of Advanced Nursing 72: 1774-88. [CrossRef]

Wilson, Jared C. 2021. Gospel Driven Ministry: An Introduction to the Calling and Work of a Pastor. Grand Rapids: Zondervan.

$\mathrm{Wu}$, Guangdong, Zhibin Hu, and Junwei Zheng. 2019. Role stress, job burnout, and job performance in construction project managers: The moderating role of career calling. International Journal of Environmental Research and Public Health 16: 2394. [CrossRef] [PubMed]

Zapf, Dieter. 2002. Emotion Work and Psychological Wellbeing: A Review of the Literature and Some Conceptual Considerations. Human Resource Management Review 12: 237-68. [CrossRef] 